that we ought to replace science by wishful thinking. I regard any such attempt to deflect scientific conclusions for political or social motives, however well-meaning, as a betrayal of science."

The situation at the British Museum (Natural History) is suspiciously comparable to that against which Huxley's criticisms were directed.

It was, however, something even more astonishing than all this that stung me, a palaeontologist and evolutionist, into activity ${ }^{7}$. This was the assurance given in writing in 1978 by the Head of the Public Services Department to the creationists ${ }^{8}$ that the museum in its new exhibition on evolution (to be opened in 1981) would make it quite clear that the theory of evolution was not a scientific theory. It transpired that this attitude stemmed from the writings of Sir Karl Popper. The museum was now concerned with "concepts of science" as adumbrated by Popper, and the articles of Platnick and Gaffney ${ }^{9}$ and even more recently Tassy ${ }^{10}$ emphasized the scientific (in the sense of Popper) nature of cladistics. In marked contrast, palaeontology, the historical side of evolution, was dismissed because it comprised unique events which were by definition unrepeatable and so not subject to test and hence not part of science. This is the view of Patterson ${ }^{11}$ which he claimed comes from Popper.

The notion that the process of evolution by natural selection is non-science was based on the idea that "survival of the fittest" is a tautology and hence unfalsifiable. On this point Popper ${ }^{12}$ wrote:

"The fact that the theory of natural selection is difficult to test has led some people, antiDarwinists, to claim that it is a tautology ...

Since the explanatory power of a tautology is obviously zero, something must be wrong here

"I mention this problem because I too belong among the culprits . . . I have changed my mind about the testability and the logical status of the theory of natural selection; and I am glad to have an opportunity to make a recantation."

Ruse $^{13}$ and Flew ${ }^{14}$ have also dealt with this. (The museum, although initially keeping faith with the creationists, has since withdrawn the film loop concerned, following the adverse review of the exhibition by Barry Cox ${ }^{15}$ (see also Miles ${ }^{16}$ ).

Popper ${ }^{17}$, following my attack ${ }^{7}$ on the ideas being peddled in his name, has emphatically dissociated himself from his self-proclaimed disciples in the following terms:

"It does appear that some people think that denied scientific character to the historical sciences, such as palaeontology, or the history of the evolution of life on Earth. This is a mistake, and I here wish to affirm that these and other historical sciences have in my opinion scientific character; their hypotheses can in many cases be tested. It appears as if some people would think that the historical sciences are untestable because they describe unique events. However, the description of unique events can very often be tested by deriving from them testable predictions or retrodictions."

With the philosophical aspect in better perspective, it became possible to consider what might lie behind the attitudes to evolution and palaeontology being unveiled by the museum's Public Services Department. My suggestions on this stimulated a certain degree of controversy.

Sir Andrew Huxley in his opening of the museum's new exhibit "Origin of Species" stated that he had "been quite unable to comprehend the suggestion that cladism is

\title{
How to classify the cladists
}

SIR - May I propose a cladogram of cladists?

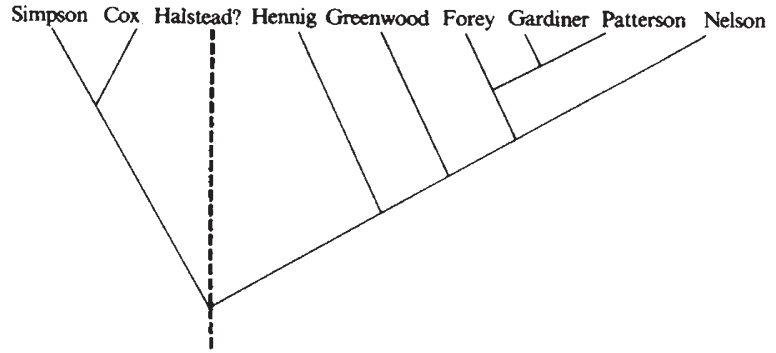

The cladogram is, of course, based only on derived characters appearing late in ontogeny; it makes no claims as to ancestry. (Apologies to Halstead, but he does display a confusing array of derived traits.)

London, UK

BRIAN LEITH

somehow antagonistic to evolution, or that cladism is linked to the theory that evolution progresses by fits and starts, or that cladism is more Marxist than other styles of

classification".

That Hennigian or classical cladistics is antagonistic to the gradualist type of evolution is surely evidenced by Rosen, Nelson and Patterson ${ }^{18}$ :

"Hennig established a criterion of demarcation between sciences and metaphysics at a time when neo-Darwinism had attained a sort of metaphysical pinnacle by imposing a burden of subjectivity and tautology on nature's observable hierarchy. Encumbered with vague and slippery ideas about adaptation, fitness, biological species and natural selection, neo-Darwinism (summed up in the "evolutionary" systematics of Mayr and Simpson) not only lacked a definable investigatory method, but came to depend, both for evolutionary interpretation and classification, on consensus or authority."

This sounds antagonistic to me.

The latest brand of cladism, the

transformed variety, has undoubtedly slid into what seems to me to be an overtly anti-evolutionist stand. Patterson ${ }^{19}$ writes:

"Hennig's 1966 book, as the title Phylogenetic Systematics suggests, was based in evolutionary theory. But as the theory of cladistics has developed, it has been realised that more and more of the evolutionary framework is inessential and may be dropped. Platnick (1980) refers to the new theory as 'transformed cladistics' and the transformation is away from dependence on evolutionary theory. In my view, the most important outcome of cladistics is that a simple, even naive method of discovering the group of systematics - what used to be called, the natural system - has led some of us to realise that much of today's explanation of nature, in terms of neoDarwinism, or the synthetic theory, may be empty rhetoric. Eldredge and Cracraft (1980) provide a detailed criticism of the transformational approach in biology, and the ensuing interest in storytelling about adaptive change."

The link between cladistics and the theory that evolution progresses by fits and starts

1. Halstead, L.B. Nature 275,683 (1978)

2. Halstead, L.B. Nature 276, 759-760 (1978)

3. Charig, A. A New Look at Dinosaurs (British Museum (Natural History), London, 1979).

4. Halstead, L.B. Noture 288, 208 (1980).

5. Cronin, J.E., Boaz, N.T., Stringer, C.B. \& Rak, Y. Nature 292, 113-122 (1981).

6 Prothero, D.R. \& Lazarus, D. B. Syst. Zool. 28 (1978).

7. Halstead, L. B. New Scientist 87, 215-217 (1980).

8. Miles, R.S. Creation News Sheet 28 (1978).

9. Platnick, N.1. \& Gaffney, E.S. Syst. Zool. 26, 360-365 (1977); 27, 137-141, 381-388 (1978).

10. Tassy, P. Int. Symp. Conceptual Methods in Palae ontology, Barcelona, 65-73 (1981).

11. Patterson, C. Evolution (British Museum (Natural History), London, 1978)

12. Popper, K. Dialectica 32, 344 (1978). (punctuated equilibria) is emphasized in particular by Cracraft ${ }^{20}$ and is certainly the type of association that a normal reader would obtain from reading Eldredge and Cracraft's Phylogenetic Patterns and the Evolutionary Process $^{21}$.

The concept of punctuated equilibria is undoubtedly linked to Marxism, according to Gould $^{22}$, who claims to be a Marxist. Gould ${ }^{22}$ sees "notions of gradualism arising largely out of a pervasive political bias [and] . . . the replacing of gradualism with the flip-like style of change which has been appreciated within Marxist philosophy for a long time."

The current drive against the concept of gradualism is motivated primarily by Marxists - this does not mean that there are not plenty of non-Marxists who agree nor does it mean that the views may not turn out to be true. What is objectionable is the distortion of scientific data for ideological purposes.

Finally, I am not opposed to either a cladistic or a Marxist approach being presented. My objection is to the attempt to impose highly controversial concepts on to the general public not by argument or discussion but simply by unsubstantiated assertion. Whalley and Gibbon ${ }^{23}$ have pointed out that the current policies being pursued by the museum are diametrically opposed to the 1972 paper to the trustees, on which they are supposedly based, where it was emphasized that the new exhibition scheme "should point out areas of doubt and speculation".

Whatever view is taken of my linking hypothesis, this does not in any way affect the factual account of what has been happening in the museum. It is to be hoped that the minor changes made in the past few weeks herald a new awareness by the trustees of their responsibility towards maintaining integrity in the natural sciences.

L. Beverly Halstead

\section{University of Reading, UK}

13. Ruse, M. Phil. Sci. 44, 638-661 (1977); New Scientist 90, $828-830$ (1981)

14. Flew, A. A Rational Animal (Clarendon, Oxford, 1978)

15. Cox, B. Nature 291, 373 (1981).

16. Miles, R.S. Nature 291, 530 (1981)

17. Popper, K. New Scientist 87, 611 (1980)

18. Rosen, D.E., Nelson, G. \& Patterson, C. in Phylogenetic Systematics (University of Illinois Press, 1979).

19. Patterson, C. Biologist 27, 234-240 (1980).

20. Cracraft, J. in Phylogenetic Analysis and Palaeontology (Columbia University Press, 1979).

21. Eldredge, N. \& Cracraft, J. Phylogenetic Patterns and the Process of Evolution (Columbia University Press, 1980). 22. Gould, S. J. Sci. Nature 3, 5-12 (1979).

23. Whalley, R. Gibbon, K. Palaeont. Ass. Circ. 105, 4 (1981). 